\title{
ビル屋上建造物による電磁波の回折特性の解析
}

\section{Analysis of the Diffraction of Electromagnetic Fields by Buildings with Rooftop Obstacles.}

\author{
正会員 岩 重二郎†, \\ 中嶋 健太浢, 学生会員上.田智也†
}

Jiro Iwashige $^{\dagger}$, Kenta Nakashima ${ }^{\dagger \dagger}$ and Tomoya Ueda $^{\dagger}$

\begin{abstract}
Estimation of the scattering of electromagnetic waves by buildings and other obstacles is very important for wireless communications in urban areas. In this paper, the electric fields of the waves, which are transmitted from one side of a building to travel over its rooftop to reach the other side were calculated on the basis of the GTD including slope diffraction for the cases where rooftop obstacles are and are not present. The fields as diffracted by a square obstacle and a conductive plate on a rooftop of a building are also discussed. The numerical results show that most of the diffracted waves that travel along the rooftop surface are slope-diffracted, and that installing a conductive plate of suitable height on the building's rooftop is a fairly effective way of improving the received level of electric field strength.
\end{abstract}

キーワード：都们内電波伝般，ビル，屋上䆃休柲，G T D, slope 回折，回折间数

\section{1. ま え がき}

ビルが林立する都市内では，電波はビルの壁やエッジ， その他の建造物等によって複雑に散乱され，その結果一 般に通信品質は劣化する。そのため，都市内の伝搬経路 を予測することは，電波資源の有効利用の観点からも大 変重要となる，例えば，市街地におけるテレビや携带電 話等の電波の伝搬を考察するとき，送信アンテナからの 見通し内では比較的強い電界強度が期待できるが，見通 し外では電界は急激に弱まる。しかし，その伝搬経路の 予測はビル等によって複雑に散乱されるために一般に容 易ではない，市街地における電波伝搬経路の推定につい てはこれまでに多くの報告がある1) 3)。これらは，主 に市街地をビルで囲まれた電波の伝搬路として解析，検 討したものである。ビル屋上を超えて伝搬するものにつ いては，Zhang が多数のビル上方の伝搬経路について考 察しているが4)，1つのビルのさらにその屋上建造物ま で詳しく検討した報告は筆者らの研究 5) 6) 以外にはない ようである。

ITE ROFT2001-15(Jan.2001) で発表

2001 年: 9 月 12 日受付, 2002 年 3 月 4 月再受付, 2002 年 4 月 16 月採録 †福阔].業大学 情報[学部

( ₹ 811-0295 福岡枋東区租向東 3-30-1, TEL 092-606-4936) †十(侏やナイ・ソフトウエア開発部

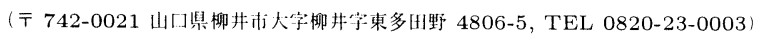

$\dagger$ Fuculty of Information Engineering, Fukuoka Institute of Technology

(3-30-1, Wajirohigashi, Higashi-ku, Fukuoka-shi 811-0295, Japan)

$\dagger \dagger$ Development Division, Yanai Software, Co., Ltd.

(4806-5, Yanai, Yanai-shi, Yamaguchi 742-0021, Japan)
本稿では，ビルの屋上を経由してその反対側に達する 電波の強さについて, 特にビル屋上の塔屋等の建造物に よる影響について考察するとともに，ビル屋上に導体板 を立てることにより，ビルや屋上建造物による電磁波の 減衰を抑制できることを示す。解析には GTD $\left.{ }^{7)} 8\right)$ を用 いた，GTDは本来完全導体による回折現象を解析する ための手法であるがここでは，Burnsideらが提案した heuristic な方法 9) 10) を用いて媒質定数を考慮し, さら にそれにLuebbersらの方法11) を参考にして，ビル屋上 の slope 回折まで含めて解析した。

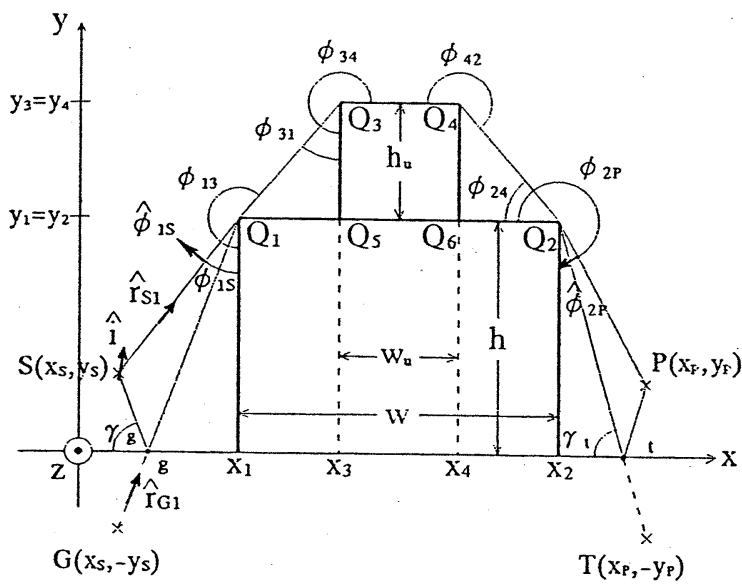

図 1 ビル屋上建造物と座槽采。

An obstacle on a building rooftop and its coordinate system. 
表 1 伀般経路。

Propagation routes.

$\begin{array}{lllll}\text { I } & \mathrm{SQ}_{1} \mathrm{Q}_{3} \mathrm{Q}_{4} \mathrm{Q}_{2} \mathrm{P} & (\mathrm{G} \cdots \mathrm{P}, & \mathrm{S} \cdots \mathrm{T}, & \mathrm{G} \cdots \mathrm{T}) \\ \text { II } & \mathrm{SQ}_{1} \mathrm{Q}_{3} \mathrm{Q}_{4} \mathrm{P} & (\mathrm{G} \cdots \mathrm{P}, & \mathrm{S} \cdots \mathrm{T}, & \mathrm{G} \cdots \mathrm{T}) \\ \text { III } & \mathrm{SQ}_{3} \mathrm{Q}_{4} \mathrm{Q}_{2} \mathrm{P} & (\mathrm{G} \cdots \mathrm{P}, & \mathrm{S} \cdots \mathrm{T}, & \mathrm{G} \cdots \mathrm{T}) \\ \text { IV } & \mathrm{SQ}_{3} \mathrm{Q}_{4} \mathrm{P} & (\mathrm{G} \cdots \mathrm{P}, & \mathrm{S} \cdots \mathrm{T}, & \mathrm{G} \cdots \mathrm{T}) \\ \text { V } & \mathrm{SQ}_{4} \mathrm{Q}_{2} \mathrm{P} & (\mathrm{S} \cdots \mathrm{T}) & & \\ \text { VI } & \mathrm{SQ}_{4} \mathrm{P} & (\mathrm{S} \cdots \mathrm{T}) & & \\ \text { VII } & \mathrm{SQ}_{2} \mathrm{P} & (\mathrm{S} \cdots \mathrm{T}) & & \\ \text { VIII } & \mathrm{S} \mathrm{B}_{3} \mathrm{Q}_{4} \mathrm{Q}_{2} \mathrm{P} & (\mathrm{S} \cdots \mathrm{T}) & & \\ \text { IX } & {\mathrm{SB} \mathrm{Q}_{3} \mathrm{Q}_{4} \mathrm{P}}_{\mathrm{X}} & (\mathrm{S} \cdots \mathrm{T}) & & \\ \text { X } & \mathrm{SCQ}_{1} \mathrm{Q}_{3} \mathrm{Q}_{4} \mathrm{Q}_{2} \mathrm{P} & (\mathrm{S} \cdots \mathrm{T}) & & \\ \text { XI } & \mathrm{SCQ}_{1} \mathrm{Q}_{3} \mathrm{Q}_{4} \mathrm{P} & (\mathrm{S} \cdots \mathrm{T}) & & \\ \text { XII } & \mathrm{SP} & (\mathrm{ST}) & & \end{array}$

\section{2. ビル屋上エッジによる電磁波の回折}

\section{1 伝搬経路}

図 1 は, 波源 $\mathrm{S}$ (送信アンテナ) からの電磁波が, ビル 屋上の建造物を経由して, ビルの反対側の観測点 $\mathrm{P}($ 受 信アンテナ) に達する様子を示している. ビル (高さ $h$, 幅 $w$ ) および屋上建造物 (高さ $h_{u}$, 幅 $w_{u}$ ) は, $z$ 方向 に無限にあるものと仮定し，それらのエッジでの回折 点を $\mathrm{Q}_{i}\left(x_{i}, y_{i}\right)(i=1,3,4,2)$ としている. また, 波源 $\mathrm{S}\left(x_{S}, y_{S}\right)$ はビルの左側にあり, 観測点 $\mathrm{P}\left(x_{P}, y_{P}\right)$ はビル の右側でビルの高さよりも低い位置にある，つまり，

$$
x_{S}<x_{1}, \quad x_{P}>x_{2}, \quad y_{P}<y_{2}
$$

\section{としている.}

波源，ビルおよび屋上建造物と観測点をこのように配 置すると，波源 $\mathrm{S}$ から観測点 $\mathrm{P}$ 一は表 1 に示すような 12 組 32 種の電波伝搬の経路が考えられる.

表中，例えば I $\mathrm{S} \mathrm{Q}_{1} \mathrm{Q}_{3} \mathrm{Q}_{4} \mathrm{Q}_{2} \mathrm{P}$ は波源 S からの電磁 波が4つのエッジ上の回折点 $\mathrm{Q}_{1}, \mathrm{Q}_{3}, \mathrm{Q}_{4}, \mathrm{Q}_{2}$ で 4 回回 折され，観測点 $\mathrm{P}$ へ達することを表し，(G‥P $)(\mathrm{G}$ は大地に対する点 Sのイメージ）は図 1 に示すように， $\mathrm{S}$ からの波がいったん大地で反射した後 4 回回折するも のを, ( S …T T) ( T は点 Pのイメージ) は4 回回折し た後大地で反射して $\mathrm{P}$ へ達するものを示している。さら に，VIII〜XIの B と C はそれぞれ入射電磁波の $\mathrm{Q}_{1} \mathrm{Q}_{5}$ 面上， $\mathrm{Q}_{3} \mathrm{Q}_{5}$ 面上での反射点を表している.

点 $\mathrm{P} て ゙$ 観測される全電磁界はもちろん，以上の 32 種 の経路のうち点 $\mathrm{P}$ 一達するものの和として計算される。

\section{$2.2 \mathrm{Q}_{1}, \mathrm{Q}_{3}, \mathrm{Q}_{4}, \mathrm{Q}_{2}$ での 4 回回折}

(1) $\mathrm{SQ}_{1} \mathrm{Q}_{3} \mathrm{Q}_{4} \mathrm{Q}_{2} \mathrm{P}$ (大地反射なし)

\section{wedge 回折}

前節で述べた表 1 の I 場合，つまり波源 $\mathrm{S}$ からの 電磁波が 4 つのエッジ $\mathrm{Q}_{1}, \mathrm{Q}_{3}, \mathrm{Q}_{4}, \mathrm{Q}_{2}$ で wedge 回折し, 観測点 $\mathrm{P}$ 一達する場合を考えよう。この 4 回の wedge 回 折界 $\boldsymbol{E}_{S 1342 P}^{w d}$ は次のように表現できる ${ }^{12)}$.

$$
\begin{aligned}
\boldsymbol{E}_{S 1342 P}^{w d}= & E_{0} \Phi_{S 1342 P}\left(\widehat{r}_{S 1} \times \hat{i} \times \widehat{r}_{S 1}\right) \\
& \cdot \overline{\boldsymbol{D}}_{S 13} \cdot \overline{\boldsymbol{D}}_{134} \cdot \overline{\boldsymbol{D}}_{342} \cdot \overline{\boldsymbol{D}}_{42 P},
\end{aligned}
$$

$$
\Phi_{S 1342 P}=\Phi\left(r_{S 1342 P}\right) \sqrt{\frac{r_{S 1342 P}}{r_{S 1} r_{13} r_{34} r_{42} r_{2 P}}} .
$$

ここに, $\widehat{r}_{S 1}$ は $\mathrm{S}$ から $\mathrm{Q}_{1}$ に向かう距離の単位べクトル， $\widehat{i}$ は $\mathrm{S}$ での電流の単位べクトル, $r_{l m}(l, m=\mathrm{S}, 1,3,4,2, \mathrm{P})$

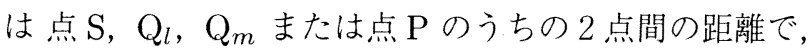

$$
\begin{aligned}
& r_{S 1342 P}=r_{S 1}+r_{13}+r_{34}+r_{42}+r_{2 P}, \\
& \Phi(r)=\frac{e^{-j k r}}{r}, \quad k=\frac{2 \pi}{\lambda}(\lambda: \text { 波長 })
\end{aligned}
$$

としている. 式 (1)の $\overline{\boldsymbol{D}}_{k l m}(k, l, m=\mathrm{S}, 1,3,4,2, \mathrm{P})$ は, 点 $\mathrm{Q}_{l}$ におけるダイアディック回折係数で,

$$
\left.\begin{array}{l}
\bar{D}_{k l m}=\widehat{z} \widehat{z} D_{k l m}^{(s)}-\widehat{\varphi}_{l k} \widehat{\varphi}_{l m} D_{k l m}^{(h)}, \\
D_{k l m}^{(s / h)}=D_{s / h}\left(r_{k l}, r_{l m}, \varphi_{l k}, \varphi_{l m}, n_{l}\right) .
\end{array}\right\}
$$

ここに，例えば $\widehat{\varphi}_{l k}$ は角度 $\varphi_{l k}$ の右回りに取った単位べ クトル， $n_{l}$ は wedge $\mathrm{Q}_{l}$ の外角 $n_{l} \pi$ を表すパラメー夕 である。さらに，上式の $D_{s / h}$ は $\operatorname{soft}(\mathrm{s}) ま た は ~ h a r d(h)$ boundaryに対するスカラー回折係数で, 次式で示され る ${ }^{10)}$.

$$
\begin{aligned}
& D_{s / h}\left(r^{\prime}, r, \varphi^{\prime}, \varphi, n\right) \\
& =\frac{-e^{-j \pi / 4}}{2 n \sqrt{2 \pi k}}\left\{\cot \left(\frac{\pi+\beta^{-}}{2 n}\right) F\left[k L a^{+}\left(\beta^{-}\right)\right]\right. \\
& +\cot \left(\frac{\pi-\beta^{-}}{2 n}\right) F\left[k L a^{-}\left(\beta^{-}\right)\right] \\
& +R_{0}^{(s / h)} \cot \left(\frac{\pi-\beta^{+}}{2 n}\right) F\left[k L a^{-}\left(\beta^{+}\right)\right] \\
& \left.+R_{n}^{(s / h)} \cot \left(\frac{\pi+\beta^{+}}{2 n}\right) F\left[k L a^{+}\left(\beta^{+}\right)\right]\right\} \text {. } \\
& L=\frac{r^{\prime} r}{r^{\prime}+r}, \quad \beta^{\mp}=\varphi \mp \varphi^{\prime}, \\
& F(x)=2 j \sqrt{x} e^{j x} \int_{\sqrt{x}}^{\infty} e^{-j \tau^{2}} d \tau, \\
& a^{ \pm}(\beta)=2 \cos ^{2}\left(\frac{2 n \pi N^{ \pm}-\beta}{2}\right), \\
& N^{ \pm}=\left[\frac{\beta \pm \pi}{2 n \pi}+\frac{1}{2}\right] \quad([\text { ] は Gauss の記号 }) .
\end{aligned}
$$

式 (5)の $R_{0}^{(s / h)}$ と $R_{n}^{(s / h)}$ は, wedge を構成する 2 平面 を 0 面 $(\varphi=0), \mathrm{n}$ 面 $(\varphi=n \pi)$ としたとき，それぞれの 面の反射係数で，それらは Fresnel の反射係数 $R^{(s / h)}$ と して次式で与えられる。

$$
\left.\begin{array}{l}
R^{(s)}(\gamma)=\frac{\sin \gamma-\sqrt{\varepsilon_{c}-\cos ^{2} \gamma}}{\sin \gamma+\sqrt{\varepsilon_{c}-\cos ^{2} \gamma}}, \\
R^{(h)}(\gamma)=\frac{\varepsilon_{c} \sin \gamma-\sqrt{\varepsilon_{c}-\cos ^{2} \gamma}}{\varepsilon_{c} \sin \gamma+\sqrt{\varepsilon_{c}-\cos ^{2} \gamma}}, \\
\varepsilon_{c}=\varepsilon_{r}-j \sigma / \omega \varepsilon_{0} \simeq \varepsilon_{r}-j 60 \sigma \lambda .
\end{array}\right\}
$$

ここに， $\gamma$ は入射方向と反射面のなす角， $\varepsilon_{c}$ は複素比誘 電率， $\varepsilon_{r}$ は比誘電率， $\sigma$ は導電率， $\lambda$ は使用波長である. 


\section{slope 回折}

今考えている 4 回回折では, エッジ $\mathrm{Q}_{3}$ で回折した波 は引続いて $\mathrm{Q}_{4}$ で回折する。 $\mathrm{Q}_{3}$ での回折後の光線はビ ル塔屋上面に沿って進むため，いわゆる slope 回折を考 慮しなければならない. 式(1)の 4 回の wedge 回折波 $\boldsymbol{E}_{S 1342 P}^{w d}$ に対する slope 回折波 $\boldsymbol{E}_{S 1342 P}^{s d}$ は次のように 書くことができる ${ }^{11)}$.

$$
\begin{aligned}
\boldsymbol{E}_{S 1342 P}^{s d}= & E_{0} \Phi_{S 1342 P}\left(\widehat{r}_{S 1} \times \widehat{i} \times \widehat{r}_{S 1}\right) \cdot \overline{\boldsymbol{D}}_{S 13} \\
& \cdot\left(\frac{j}{2 k r_{34}} \frac{\partial \overline{\boldsymbol{D}}_{134}}{\partial \varphi_{34}} \cdot \frac{\partial \overline{\boldsymbol{D}}_{342}}{\partial \varphi_{43}}\right) \cdot \overline{\boldsymbol{D}}_{42 P}
\end{aligned}
$$

結局, $\mathrm{Q}_{1}, \mathrm{Q}_{3}, \mathrm{Q}_{4}, \mathrm{Q}_{2}$ で 4 回回折する波 $\boldsymbol{E}_{S 1342 P}^{d}$ は, slope 回折まで考慮すると, 式 (1) と式 (8)の和として次 のように表現される。

$$
\begin{aligned}
\boldsymbol{E}_{S 1342 P}^{d}= & \boldsymbol{E}_{S 1342 P}^{w d}+\boldsymbol{E}_{S 1342 P}^{s d} \\
= & E_{0} \Phi_{S 1342 P}\left(\widehat{r}_{S 1} \times \widehat{i} \times \widehat{r}_{S 1}\right) \\
& \overline{\boldsymbol{D}}_{S 13} \cdot \overline{\boldsymbol{S}}_{1342} \cdot \overline{\boldsymbol{D}}_{42 P} \\
\overline{\boldsymbol{S}}_{1342}= & \overline{\boldsymbol{D}}_{134} \cdot \overline{\boldsymbol{D}}_{342}+\frac{j}{2 k r_{34}} \frac{\partial \overline{\boldsymbol{D}}_{134}}{\partial \varphi_{34}} \cdot \frac{\partial \overline{\boldsymbol{D}}_{342}}{\partial \varphi_{43}}
\end{aligned}
$$

（2） $\mathrm{G} \mathrm{Q}_{1} \mathrm{Q}_{3} \mathrm{Q}_{4} \mathrm{Q}_{2} \mathrm{P}$ (大地反射後 4 回回折)

波源 $\mathrm{S}$ からの波が大地で 1 回反射した後に $\mathrm{Q}_{1}, \mathrm{Q}_{3}$, $\mathrm{Q}_{4}, \mathrm{Q}_{2}$ で 4 回回折され, 観測点 $\mathrm{P}$ 一達する波 $\boldsymbol{E}_{G 1342 P}^{d}$ を考えよう，この場合は，図 1 からわかるように, 式 (1) (10)の各量を $y_{S} \rightarrow-y_{S}$ として, 地面の反射係数 を掛ければよい。

図 1 の点 $\mathrm{g} に$ におる反射係数は, 次のようなダイア ディック反射係数 $\overline{\boldsymbol{R}}_{S g 1}$ の形で表現できる.

$$
\overline{\boldsymbol{R}}_{S g 1}=\widehat{h} \widehat{h} R^{(s)}\left(\gamma_{g}\right)+(\widehat{t} \widehat{t}-\widehat{n} \widehat{n}) R^{(h)}\left(\gamma_{g}\right) .
$$

上式の単位ベクトル $(\widehat{n}, \widehat{h}, \widehat{t})$ の関係を図 2 に示す。入 射波の進行方向を $\widehat{r}_{S g}$ とし， $\widehat{r}_{S g}$ が境界面となす角を $\gamma_{g}$ , $\widehat{n}$ を境界面の法線ベクトル， $\widehat{h}$ を入射面 (=反射面) へ の垂直ベクトル， $\hat{t}$ を入射面内の境界面への接線ベクト ルとすると，これらの間には次のような関係がある。

$$
\left.\begin{array}{l}
\widehat{h}=\frac{\widehat{r}_{S g} \times \widehat{n}}{\left|\widehat{r}_{S g} \times \widehat{n}\right|}, \quad \widehat{t}=\widehat{n} \times \widehat{h}, \\
\left|\widehat{r}_{S g} \times \widehat{n}\right|=\sin \left(\frac{\pi}{2}-\gamma_{g}\right)=\cos \gamma_{g}
\end{array}\right\}
$$

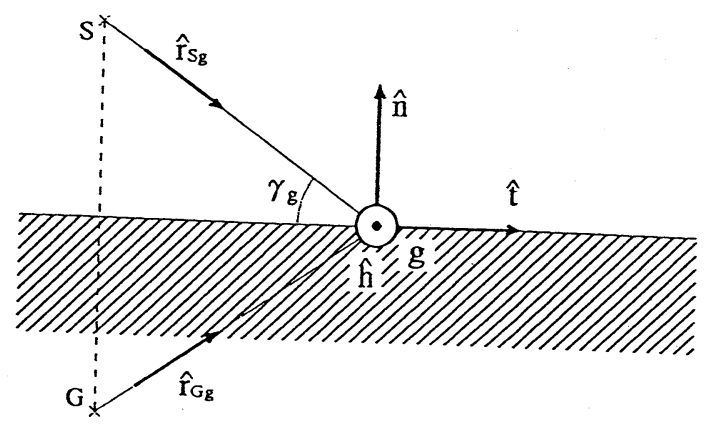

図 2 単位ベクトル $\hat{r}_{S g}, \hat{n}, \hat{h}, \hat{t}$ と入射角 $\gamma_{g}$. Unit vectors $\hat{r}_{S g}, \hat{n}, \hat{h}, \hat{t}$ and an angle $\gamma_{g}$.
したがって，この場合の回折界 $\boldsymbol{E}_{G 1342 P}^{d}$ は式 (9)に式 (11)のダイアディック反射係数を掛けた形で，次のよう に表現できる。

$$
\begin{aligned}
\boldsymbol{E}_{G 1342 P}^{d}= & E_{0} \Phi_{G 1342 P}\left(\widehat{r}_{S g} \times \widehat{i} \times \widehat{r}_{S g}\right) \\
& \cdot \overline{\boldsymbol{R}}_{S g 1} \cdot \overline{\boldsymbol{D}}_{g 13} \cdot \overline{\boldsymbol{S}}_{1342} \cdot \overline{\boldsymbol{D}}_{42 P} .
\end{aligned}
$$

(3) $\mathrm{S} \mathrm{Q}_{1} \mathrm{Q}_{3} \mathrm{Q}_{4} \mathrm{Q}_{2} \mathrm{~T}$ ( 4 回回折後大地反射)

波源 $\mathrm{S}$ からの波が $\mathrm{Q}_{1}, \mathrm{Q}_{3}, \mathrm{Q}_{4}, \mathrm{Q}_{2}$ で 4 回回折した 後, 大地上の点 $\mathrm{t}$ (図 1 参照) で反射する波 $\boldsymbol{E}_{S 1342 T}^{d}$ は 式 (13) と同様に考えて，次のように書ける.

$$
\begin{aligned}
\boldsymbol{E}_{S 1342 T}^{d}= & E_{0} \Phi_{S 1342 T}\left(\widehat{r}_{S 1} \times \hat{i} \times \widehat{r}_{S 1}\right) \\
& \cdot \overline{\boldsymbol{D}}_{S 13} \cdot \overline{\boldsymbol{S}}_{1342} \cdot \overline{\boldsymbol{D}}_{42 t} \cdot \overline{\boldsymbol{R}}_{2 t P}
\end{aligned}
$$

ここに, $\overline{\boldsymbol{R}}_{2 t P}$ はエッジ $\mathrm{Q}_{2}$ からの波が点 $\mathrm{t}$ で反射し点 $\mathrm{P}$ へ向かうダイアデイック反射係数である.

(4) $\mathrm{G} \mathrm{Q}_{1} \mathrm{Q}_{3} \mathrm{Q}_{4} \mathrm{Q}_{2} \mathrm{~T}$ ( 4 回回折の前後で反射)

4 つのエッジ $\mathrm{Q}_{1}, \mathrm{Q}_{3}, \mathrm{Q}_{4}, \mathrm{Q}_{2}$ での 4 回回折の前後で, 大地反射する波 $\boldsymbol{E}_{G 1342 T}^{d}$ は, 式 (13),(14) と同様次のよ うに表現できる。

$$
\begin{aligned}
\boldsymbol{E}_{G 1342 T}^{d}= & E_{0} \Phi_{G 1342 T}\left(\widehat{r}_{S g} \times \widehat{i} \times \widehat{r}_{S g}\right) \\
& \cdot \overline{\boldsymbol{R}}_{S g 1} \cdot \overline{\boldsymbol{D}}_{g 13} \cdot \overline{\boldsymbol{S}}_{1342} \cdot \overline{\boldsymbol{D}}_{42 t} \cdot \overline{\boldsymbol{R}}_{2 t P}
\end{aligned}
$$

以上述べたように，表 1 の II $\sim \mathrm{XI}$ の各回折界も同様 に計算できる．特に，II〜IV， VIII〜XI では， $\mathrm{Q}_{3}$ に続 いて $\mathrm{Q}_{4}$ で回折されるため, 式 (8)の slope 回折を考慮 しなければならない。

\section{3 直接界 $(\mathrm{SP}) \cdot$ 反射界 $(\mathrm{ST})$}

波源 $\mathrm{S}$ がビルの高さより充分高く, 観測点 $\mathrm{P}$ がビルよ り充分離机てあるときは， $\mathrm{S}$ からの波は，直接 $\mathrm{P}$ 一達す る。直接波 $\boldsymbol{E}_{S P}^{i}$ は $\mathrm{SP}$ 間の距離を $r_{S P}$, その単位べク トルを $\widehat{r}_{S P}$ とすると，次のように書ける。

$$
\boldsymbol{E}_{S P}^{i}=E_{0} \Phi\left(r_{S P}\right)\left(\widehat{r}_{S P} \times \widehat{i} \times \widehat{r}_{S P}\right)
$$

同様に, 大地上の点 $\mathrm{t}$ で反射する反射波 $\boldsymbol{E}_{S T}^{r}$ は

$$
\boldsymbol{E}_{S T}^{r}=E_{0} \Phi\left(r_{S T}\right)\left(\widehat{r}_{S T} \times \widehat{i} \times \widehat{r}_{S T}\right) \cdot \overline{\boldsymbol{R}}_{S t P}
$$

となる。

\section{4 全電界}

全電界 $\boldsymbol{E}^{t}$ は表 1 の各成分の和として, 形式的に次の ように表現される。

$$
\boldsymbol{E}^{t}=\sum_{\mathrm{I}}^{\mathrm{XII}}\left(\boldsymbol{E}_{S P}^{i}, \boldsymbol{E}_{S T}^{r}, \boldsymbol{E}_{\ldots}^{d}\right)
$$

\section{3. 数 值 計 算}

図 3 は,ビルをモデルとした導体壁を用い，周波数 $f=10 \mathrm{GHz}(\lambda=3 \mathrm{~cm})$, 水平偏波 $(\hat{i}=\hat{z})$ での数值計算結 果を測定值と比較したものである。送受信アンテナと しては,ダブル・リッジドガイド・ホーンアンテナを用 


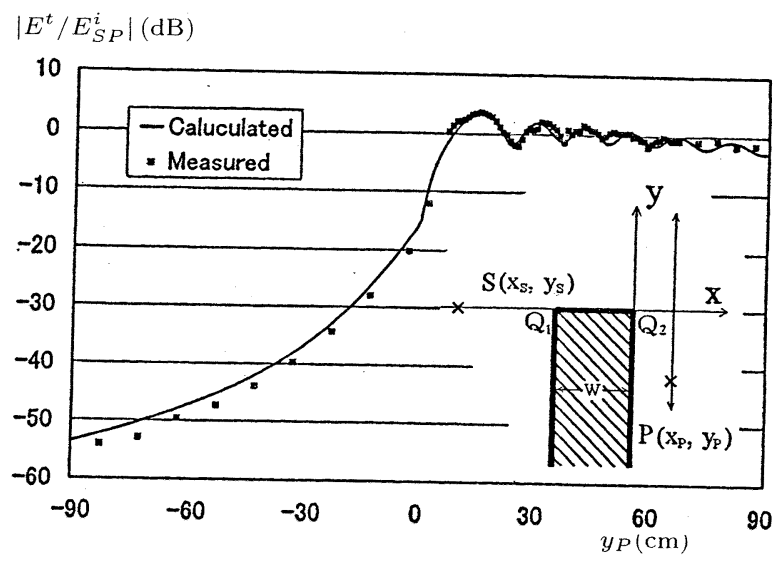

(a)フェンスなし

$\left|E^{t} / E_{S P}^{i}\right|(\mathrm{dB})$

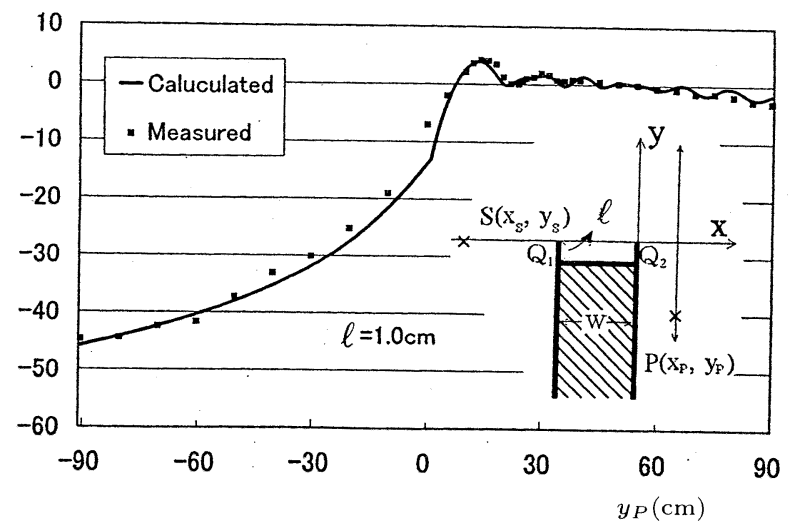

(b) フェンスあり

図 3 導体壁による散乱界の理渝値と测定結果との比較 (水平仾波). $\left(f=10 \mathrm{GHz}, w=10.4 \mathrm{~cm}, x_{S}=-54.4 \mathrm{~cm}, y_{S}=0, x_{P}=30.2 \mathrm{~cm}\right)$ Comparison of numerical calculation and experimental results of the fields scattered by a conducting slab (horizontal polarization).

い，ネットワーク・アナライザのタイムドメイン機能に より点 $\mathrm{S}, \mathrm{P}$ の位置決めと周囲からの不要散乱波の除去 を行った。また，導体壁はアルミ板で作成し，その幅を $w=10.4 \mathrm{~cm}$ とし，長さ (図 3 の紙面に垂直方向) $2 \mathrm{~m}$, 高さ $(h)$ を $1 \mathrm{~m}$ と充分長くして床からの反射は無視した. 同図 (a) では波源の高さを導体壁の上面 $\left(y_{S}=0\right)$ と一 致させ, 観測点 $\mathrm{P}$ を $y_{P}=0$ を中心に上下に変化さ せ, $y_{P}=0$ 点での直接波の強さ $\left|E_{S P}^{i}\right|$ を $0 \mathrm{~dB}$ として 表示している. GTDによると，このようなモデルでは 2 つのエッジ $\mathrm{Q}_{1}, \mathrm{Q}_{2}$ のいわゆる遷移領域が重なるため, wedge 回折のみでは誤差を生じるのみならず，水平偏波 では陰の領域 $\left(y_{P}<0\right)$ では界は 0 となり, $y_{P}=0$ で不 連続となる。しかしながら，本稿では slope 回折まで含 めて計算しているため, その結果は $y_{P}=0$ で連続とな り測定値ともよく一致していることがわかる.

一般にビル屋上の周囲にはフェンス (parapet) が設け られているが，そのモデルとして，導体壁上面両端に高

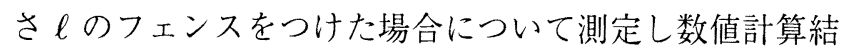
果と比較したものが図 3(b) で, フェンスの先端の回折点 $\mathrm{Q}_{1}, \mathrm{Q}_{2}$ と同じ高さに波源 $\mathrm{S}$ を置いている.このモデル
では，両端フェンスのために slope 回折波は非常に小さ くほとんどが $\mathrm{Q}_{1}, \mathrm{Q}_{2}$ での wedge 回折波と導体壁上面で の反射波であるが，これも数值計算結果は測定值とよく 合っている。なお，図 $3(\mathrm{a}),(\mathrm{b})$ ともに 2 つの回折点の延 長上に波源を置いているため, slope 回折まで考慮して も数值計算結果は $y_{P}=0$ でその勾配にわずかな不連続 が認められる13).

図 4,5 は水平偏波 (Horizontal $; \hat{i}=\hat{z}$ ) と垂直偏波 (Vertical ; $\hat{i}=\hat{y}$ ) について, 周波数 $f=500 \mathrm{MHz}$, ビ ルの大きさは $(w=25 \mathrm{~m}, h=30 \mathrm{~m}), x_{2}=0$ とし, ビル屋 上建造物 $\left(w_{u}=h_{u}=5 \mathrm{~m}, x_{3}=-15 \mathrm{~m}\right)$ がある場合 ( 2 roofs), 屋上に何もない場合 (1 roof), 屋上中央に 導体板 $\left(w_{u}=0, h_{u}=10 \mathrm{~m}, x_{3}=x_{4}=-12.5 \mathrm{~m}\right)$ を 立てた場合 (plate) を, ビルがない大地のみの場合 (nobuilding) と比較している. 波源 $\mathrm{S}$ の位置は $\left(x_{S}=-1 \mathrm{~km}\right.$, $\left.y_{S}=5 \mathrm{~m}, 60 \mathrm{~m}\right)$, 受信点 $\mathrm{P}$ は, その高さを $y_{P}=1.5 \mathrm{~m}, 10 \mathrm{~m}$ とし, ビル右壁面からの距離 $\left(0 \leqq x_{P} \leqq 500 \mathrm{~m}\right)$ に対する電 界強度を $E_{0}=1$ として $\mathrm{dB}$ 表示したものである.ビルと 屋上建造物はコンクリート $\left(\varepsilon_{r}=6.76, \sigma=0.0023[\mathrm{~S} / \mathrm{m}]\right)$, 大地は $\varepsilon_{r}=15, \sigma=0.005[\mathrm{~S} / \mathrm{m}]$ とした。

図 4 は, 携帯電話で使われるであろう観測点の高さ $y_{P}=1.5 \mathrm{~m}$ の場合で，同図 (a),(b) は水平偏波，(c),(d) は垂直偏波であり，また (a) と (c) は波源の高さがビル より低い $y_{S}=5 \mathrm{~m}$ で, (b), (d) はビルやその上の建造物 や導体板より高い $y_{S}=60 \mathrm{~m}$ の場合のビルの反対側での 電界強度の変化の様子を示している， $x_{P}$ の変化ととも に電界が大きく振動しているのは，受信点付近での大地 による反射の影響である。(a)では，no-buildingの曲線 は他の 3 つとあまり差はなく，水平偏波で，波源・観測 点ともに低い位置にあるときは，大地による反射の影響 で，ビルがあるときとないときとの差は小さくて，充分 遠方 $\left(x_{P}<300 \mathrm{~m}\right)$ では導体板付きビルの方がむしろ強く なっていることがわかる. 他の $3 つ((\mathrm{~b}),(\mathrm{c}),(\mathrm{d}))$ は, ビ ルの存在で, $20 \mathrm{~dB}$ 程度以上の減衰がある。また，波源 がビルより低い (a) と (c) を見ると, 導体板がある場合 (plate) は, 1 roof 2 roofs より，10dB 以上減衰が小 さいことがわかる。これは，ある程度以上の高さの導体 板では, 波源からの波が, ビルエッジで複数回回折する 波より，導体板で 1 回回折する波の方が減衰が小さくな るためで，その効果は水平偏波 (a)より垂直偏波 (c) の 方が大きいことがわかる．波源がビルより高い $((\mathrm{b}),(\mathrm{d}))$ と, ビルエッジでの回折回数が少なくなるため, 全体に 減衰は小さい。同図 (a),(c) ではまた, 1roof と2roofsの slope 回折を考慮しない (式 (10)の第 2 項=0) 場合の計 算結果を示しているが， slope 回折を含む結果に比べて， いずれも $20 \mathrm{~dB}$ 以上小さくなっていて，屋上を伝わる回 折波はほとんどが slope 回折によるものであることがわ かる。一方，同図 (b),(d) では，波源がビルより高い位 置にあるために，回折点 $\mathrm{Q}_{2}$ または $\mathrm{Q}_{4}$ による 1 回回折 

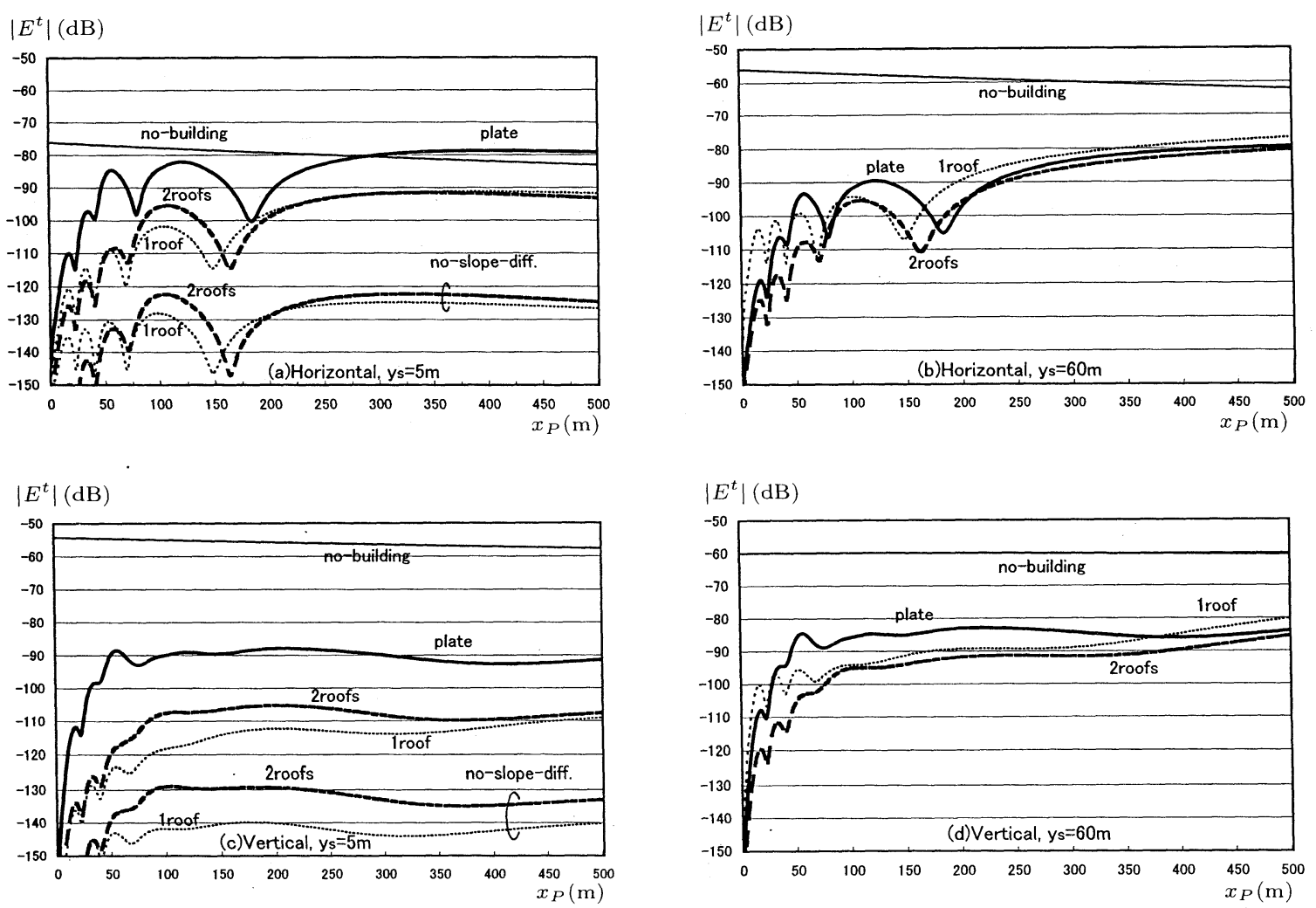

図 4 屋上建造物付きビルを越えた点 $\mathrm{P}$ での受信電界 $\left(y_{P}=1.5 \mathrm{~m}\right)$.

( $f=500 \mathrm{MHz}, h=30 \mathrm{~m}, w=25 \mathrm{~m}, h_{u}=w_{u}=5 \mathrm{~m}, x_{S}=-1 \mathrm{~km}, E_{0}=1$ )

Received fields at $\mathrm{P}$ diffracted by the building with the obstacle $\left(y_{P}=1.5 \mathrm{~m}\right)$.
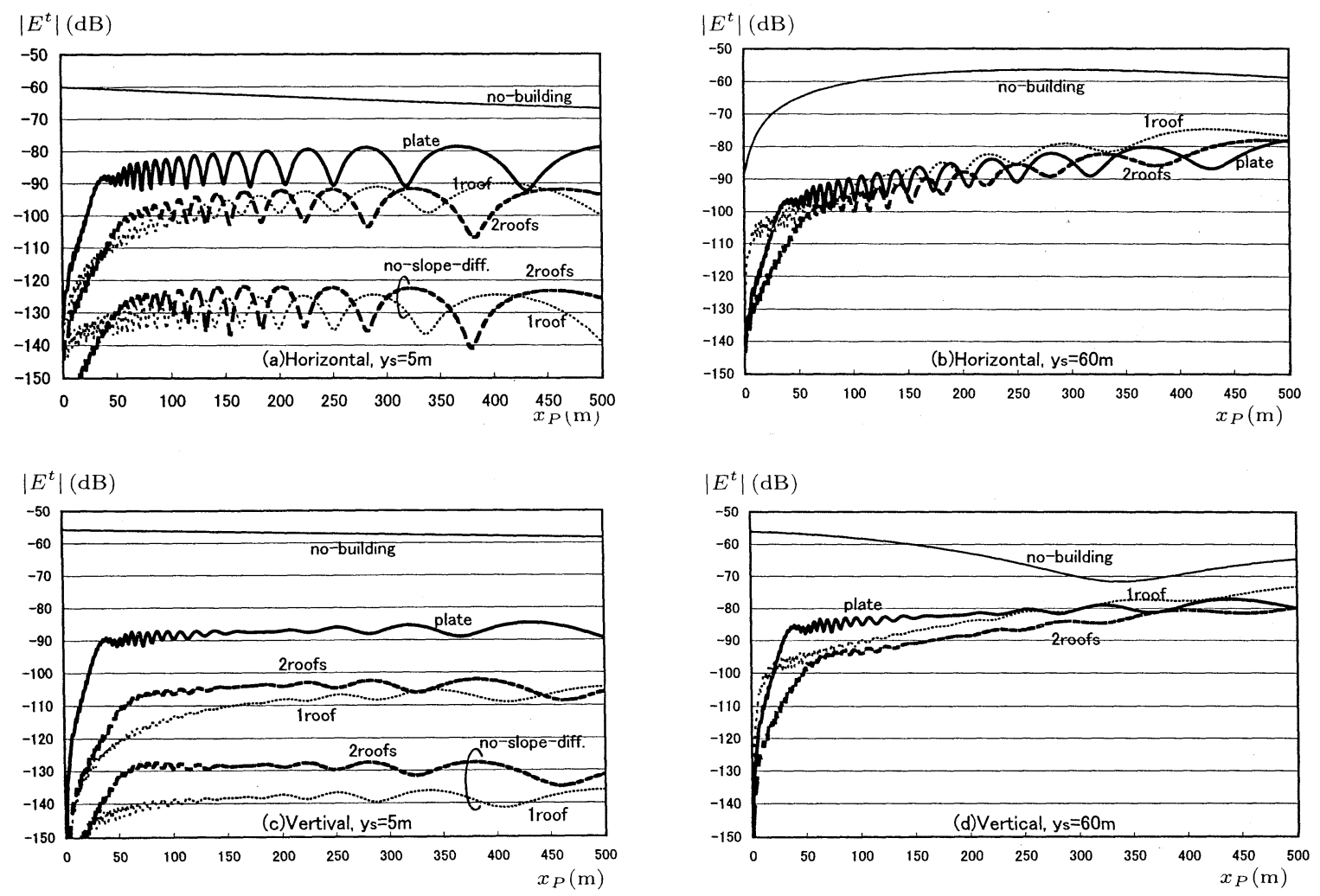

図 5 屋上建造物付きビルを越えた点 $\mathrm{P}$ での受信電界 $\left(y_{P}=10 \mathrm{~m}\right)$

( $\left.f=500 \mathrm{MHz}, h=30 \mathrm{~m}, w=25 \mathrm{~m}, h_{u}=w_{u}=5 \mathrm{~m}, x_{S}=-1 \mathrm{~km}, E_{0}=1\right)$

Received fields at $\mathrm{P}$ diffracted by the building with the

obstacle $\left(y_{P}=10 \mathrm{~m}\right)$. 
波が主要項となり slope 回折による影響は小さい。

図 5 は，一般家屋屋上のテレビ受信アンテナの高さを 想定した $y_{P}=10 \mathrm{~m}$ の場合で，同じく $0 \mathrm{~m} \leqq x_{P} \leqq 500 \mathrm{~m}$ での電界強度の変化の様子を示す. 図 4 と同様に, 低い 波源 $\left(y_{S}=5 \mathrm{~m}\right)$ のとき, ビル屋上に導体板を立てること により，ビルによる減衰は抑えられ，その効果は同じく 垂直偏波の方が大きいことがわかる. slope回折の影響 も，図 4 と同様の傾向にある。

他の周波数 $(100 \mathrm{MHz}, 1.5 \mathrm{GHz}$ 等) でも同様の計算を 行ったが, 周波数を変えても図 4,5 の結果と同様な傾向 であることが分かった。ささらに，屋上導体板を導体三角 屋根 ${ }^{6)}$ や厚さ0のコンクリート板に置き換えて計算して みても，あまり変化はなく，導体板を設置することがビ ル屋上での回折回数を少なくすることに寄与しているこ とがわかる。

以上のことから, 図 1 のようにビルを越えて電磁波が 伝搬するとき, それによる電磁波の減衰は, ビル屋上に 適当な高さの導体板を立てることによってかなり抑制で きることがわかった。

なお，ビルを完全導体と仮定すると，その屋上表面を 伝わる回折波は水平偏波では式 (10)の第 1 項が 0 となっ て slope 回折のみに, 垂直偏波では第 2 項が非常に小さ くなってほとんどが wedge 回折となる。

\section{4.むすび}

市街地において, 基地局の見通し外で電波を利用しよ うとするとき，ビルの屋上を越えてくる電波を利用する ことが考えられる。本稿では，そのようなビルとその屋 上に建造物がある場合，それらを越えて伝搬する電波の 電界強度についてビル屋上での slope 回折まで含め GTD を用いて解析し，その数值計算結果について考察した. その結果, ビルや屋上建造物のエッジによる回折回数が 少ないほど受信電界強度が強くなること, したがって, 適当な高さの導体板をビル屋上に取り付けることによっ て回折回数が減り, 受信電界強度はかなり改善されるこ と, それは水平偏波より垂直偏波の方が効果が大きいこ と, さらに, 波源, 観測点ともにビルよりも低い位置に ある水平偏波では, ビルがないよりむしろ強い電界強度 が得られる場合があること等がわかった。なお，携帯電 話やPHSに関しては, 最近利用者の急増に伴って, そ のサービスゾーンであるセルを縮小する傾向にあるが, 上述の結果を逆に利用して回折回数を増やす工夫をする ことによって，電磁波の遠方への伝搬を抑えることがで きる。

また, slope 回折に関しては, 導体表面を伝わる垂直 偏波の slope 回折波が非常に小さいのに対し, ビルの媒 質をコンクリートと仮定したときのビルや屋上建造物の 屋上表面を伝わる回折波は水平, 垂直偏波ともに slope 回折波が大きく寄与していることが明らかになった。
本稿では, ビルが紙面に垂直で無限に長い 2 次元問題 に限って解析したが, 今後, ビルが有限長の場合, ある いはエッジに斜め入射するような 3 次元問題についても 検討する予定である.

\section{[文献]}

1) A.J.Goldsmith and L.J.Greenstein: "A Measure-ment-Based Model for Predicting Coverage Areas of Urban Microcells", IEEE J. Sel. Areas Commun., 11, 7, pp.1013-1023 (Sept.1993).

2) V.Erceg, A.J.Rustako and R.S.Roman:"Diffraction Around Corners and Its Effects on the Microcell Coverage Area in Urban and Suburban Environments at $900 \mathrm{MHz}, 2 \mathrm{GHz}$, and $6 \mathrm{GHz}$, IEEE Trans. Vechicular Tech., 43, 3, pp.762-766 (Aug.1994).

3）今卡，藤师:”レイトレースを用いた找街地対応移動通信伝搬推定システム”, 信学技報, RCS97-37,pp.31-38 (June 1997).

4) W.Zhang: "A Wide-Band Propagation Model Based on UTD for Cellular Mobile Radio Communications", IEEE Trans. Antennas \& Propag., 45, 11, pp.1669-1678 (Nov.1997).

5）岩重，中㴧，川ト:”ビル屋上に立てた導体板による電磁波の散乱, 映情技報, ROFT2000-8,pp.39-44 (Jan. 2000).

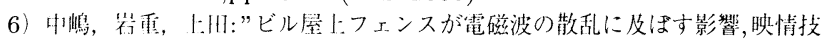
報, ROFT2001-3,pp.11-14 (Jan. 2001)

7) J.B.Keller: "Geometrical Theory of Diffraction", J.Opt.Soc.Am., 52, 2, pp.116-130 (Feb.1962).

8) R.G.Kouyoumjian and P.H.Pathak:" A Uniform Geometrical Theory of Diffraction for an Edge in Perfectly Conducting Surface", Proc. IEEE, 62, 11, pp.1448-1461 (Nov.1974).

9) W.D.Burnside and K.W.Burgener:"High Frequency scattering by a Thin lossless dielectric slab", IEEE Trans. Antennas \& Propag., AP-31, 1, pp.104-110 (Jan.1983).

10) R.J.Luebbers: "Finite Conductivity Uniform GTD versus Knife Edge Diffraction in Prediction of Propagation Path Loss", IEEE Trans. Antennas \& Propag., AP-32, 1, pp.70-76 (Jan.1984).

11) R.J.Luebbers:"A Heuristic UTD Slope Diffraction Coefficient for Rough Lossy Wedges", IEEE Trans. Antennas \& Propag., 37, 2, pp.206-211 (Feb.1989).

12）崔重 ...郎: ”複数導体くさびによる電磁波の多重回折”, 信学諭 $(B), \mathbf{J 7 0 - B}$, 4, pp.483-488 (Apr.1987).

13) P.D.Holm:" A New Heuristic UTD Diffraction Coefficient for Nonperfectly Conducting Wedges", IEEE Trans. Antennas \& Propag., 48, 8, pp.1211-1219 (Aug.2000).

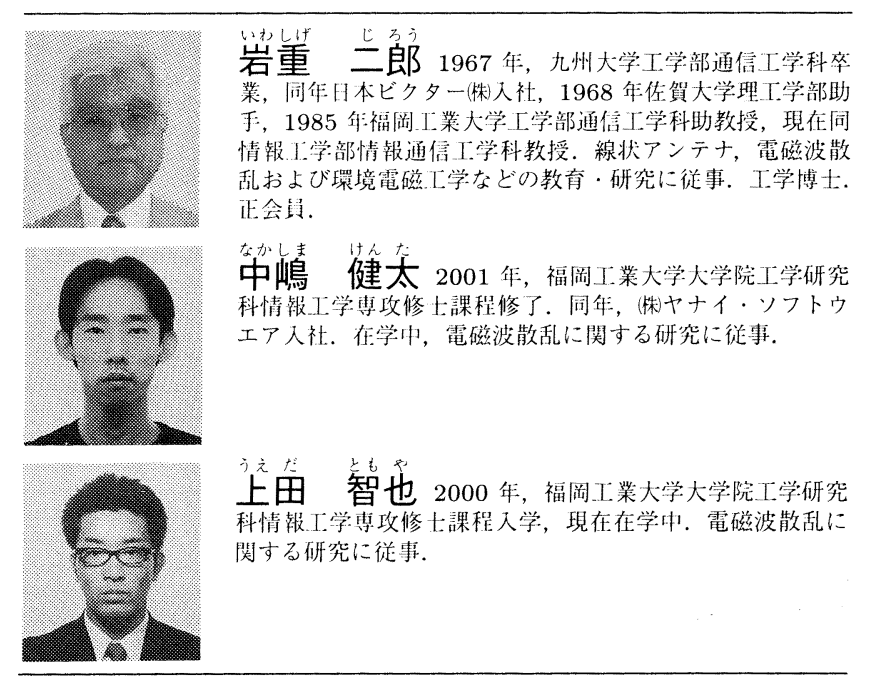

